\title{
Sustainable Enterprises:
}

\section{Crisis Management and Culture Transformation for BP}

\author{
Diane Huberman Arnold ${ }^{1} \&$ Ruth McKay ${ }^{2}$ \\ ${ }^{1}$ Sprott School of Business and Department of Philosophy, Carleton University, Ottawa, Canada \\ ${ }^{2}$ Sprott School of Business, Carleton University, Ottawa, Canada \\ Correspondence: Ruth McKay, Sprott School of Business, Carleton University, 1125 Colonel By Drive, Ottawa, \\ Ontario, K1S 5B6 Phone \# (613) 520-2600 ext.6013. E-mail: rmckay@connect.carleton.ca
}

Received: June 7, 2013

Accepted: June 21, 2013

Online Published: June 24, 2013

doi:10.5430/bmr.v2n3p16

URL: http://dx.doi.org/10.5430/bmr.v2n3p16

\begin{abstract}
Corporate sustainability includes many normal business practices. The oil spill in the Gulf of Mexico provides a classic example of how failure to be sustainable can lead to an overall organizational failure of mandate, and a failure to serve stakeholders. BP plc was faced with managing the crisis and examining the causes of its organizational failure. At the core of the issue is a failed organizational culture. This paper examines what events and organizational values have led to the crisis and what changes to organizational culture would be required, to avoid a repeat event and begin to create a sustainable organization.
\end{abstract}

Keywords: Sustainability, Crisis management, Organizational culture, Oil spill

\section{Introduction}

Normal business practices, which form and sustain the economy, belong to the common or public good by benefiting society as a whole. As such commerce can be viewed as an ethical enterprise. The common good is served when an organization is successful, profitable, creates employment, develops research and technology, sustains pension funds and retirement plans, provides goods for consumers, supports communities and protects the environment, or donates to environmental causes. These, among a host of other standard business practices, are all ethical purposes and enterprises, which benefit the business's stakeholders (Huberman Arnold and Arnold, 2003). Thus, business seen in this manner, already involves ethics (Sen, 2004).

We may call these ethical purposes the "oxygen" of a corporation's existence (Sen, 2004). However, when a corporation ceases to perform these functions, it does not sustain itself. There are many senses to the concept of sustainability that is important to business such as sustaining the environment, sustaining the community or sustaining economic stability. The oil spill in the Gulf of Mexico has rapidly shifted BP plc (BP) from an organization benefiting society to one that may no longer be sustainable. BP, originally known as Anglo-Persian Oil Company in 1909, later, in 1954 as British Petroleum and more recently as BP plc (BP, 2013), has been impacted financially by the spill, significantly deflating many pension funds in Britain. Lives and jobs have been lost, communities have been devastated and ecosystems destroyed. The focus here is that of sustaining a business itself, i.e. keeping it going. This sense must surely be the fundamental sense of sustainability. Long ago, Carroll's pyramid grounded economic sustainability as the first order of corporate responsibility (Carroll, 1991). If the business goes under, no other responsibilities or activities are possible. Even Obama in the Gulf of Mexico oil spill recognized the importance of keeping BP viable enough to pay for the damage it has caused (Globe and Mail, June 17, 2010). Shifting the burden of the clean up and resultant BP debt to government and the tax payer would have created only further problems.

This paper will examine sustainability as applied to BP. It will look at BP's past practices and likely future practices based on concerns of responsibility and organizational longevity. The primary question is how sustainable is BP. The paper will initially examine issues of trust and the treatment of stakeholders. Next it will consider if BP is a broken organization in light of the oil spill in the Gulf of Mexico and previous BP accidents. Finally, efforts by BP to manage crisis and organizational transformation towards a more sustainable organization will be considered. The value of this paper is in applying the question of sustainability to a case study. BP has not had just one accident but 
many and yet the organization survives and thrives. As such one must ask how sustainability is viewed and implemented.

\section{Trust and the Treatment of Stakeholders}

A corporation best pursues its moral purposes, when all its stakeholders are well served and well treated (Karakowsky, Archie \& Buchholtz, 2005). Like Sen, we believe that the basis of this treatment is a matter of trust. Stakeholders relate to the company through mutual trust, in the belief that each will be treated fairly, decently and honestly - in essence the good treatment of all stakeholders (Sen, 2004). This is a tenuous concept of trust, easily granted and easily shattered (Putnam, 2000).

This good treatment of stakeholders includes, but is not limited to, moral management and moral contracts, focus on a triple bottom line, work-life balance within the company, effective and proactive risk management, transparency in all decision-making and policy guidance, shared risks and benefits, good leadership including fulfilled fiduciary responsibilities and shared decision-making, avoiding moral hazard, and protection - financial and physical - of all the vulnerable and powerless stakeholders. Executives recognize the importance of such corporate activities. In 2005 , a study by the Economist Intelligence Unit reported that 88 per cent of executives believe consideration of Corporate Social Responsibility (CSR) is central and important in business decisions and are linked to better financial results for an organization. CSR is a management approach that is built on trust and stakeholder respect.

All these desirable qualities of decent treatment seem essential for success and sustainability, but are often hard for a company to achieve. There is no magic bullet, no ethical formula, no compliance or integrity strategy, no corporate citizenship framework that will force the emergence or maintain the existence of these sustaining qualities within an organization. Nothing guarantees that an organization will do the right thing, protect itself and its stakeholders against unsustainability, or survive in a hostile and competitive world. The BP oil spill is a prime example of how difficult sustainability is to achieve and trust to maintain. For an oil company, trust is a critical value as it is only through trust by government and other stakeholders that a company like BP is given drill opportunities in developed countries like the United States.

\section{The Broken Organization}

In the morally good and successful business, all those sustaining qualities are in play. Le Carré, himself no friend of rich, powerful multi-nationals, on the related theme of the survival of a state, wrote that a "quorum of essential responsibilities" is necessary for any organization to remain sustainable over time (le Carré, 2000). A business where none of these sustaining qualities, or only a limited number of them is in existence, is a failed or broken organization, beyond the help of any cultural transformation. The mutual trust sustaining the stakeholders, and their belief in the company, will dissipate (or fail to be developed) if an organization is unable or unwilling to establish and develop sustainable practices with a plurality of stakeholders at the core. For le Carré, if sustainable practices are not developed, the contract between an organization and its stakeholders has also failed (le Carré, 2000).

Internal symptoms of imminent failure include low employee morale, low employee retention rates, managerial misconduct, hubris, a culture of arrogance, bullying and sexual harassment, unreasonable demands for loyalty and profit-making, lack of transparency, a steep vertical hierarchy of decision-making, a disregard for risk and harm, indifference to less powerful stakeholders' needs and above all, an erosion of the values and ethical purposes which define its key responsibilities (McKay, Huberman Arnold, Fratzl, \& Thomas, 2008, and Crane and Matten, 2010). An organization suffering these symptoms is thus at risk of further failures, crises waiting to happen.

Such a crisis, a defining moment, may be precipitated by a particularly egregious event, a loss of financial value, the impact of nature or accident, serious misconduct or malfeasance. What may be lost are lives, health, money or ecosystems. What are irredeemably forsaken are reputation and trust. A sterling and paradigm example of this fall from grace is the recent case of BP, Britain's largest multinational, and the third largest oil company in the world (Lyall \& Werdigier, 2010).

\section{BP's Oil Spill}

In September 2009, BP tapped into the Tiber oilfield six miles beneath the Gulf of Mexico floor. BP, with the assistance of Transocean, a drilling contractor, sank the deepest oil well known to date. The well broke new boundaries in oil extraction and added to BP's image of innovation and leadership in the industry (Coy and Reed, 2010). It was a timely move by BP as the U.S. was debating whether to support more undersea drilling. Shortly thereafter, BP tapped into the Macondo deep water well site 40 miles off the Louisiana coast. Macondo was a less challenging site than the Tiber oilfield, but the process went terribly wrong. On Aril $20^{\text {th }}, 2010$, the drilling rig the 
Deepwater Horizon exploded, killing eleven workers and releasing thousands of barrels of oil into the Gulf of Mexico (Somaiya, 2010).

The accident occurred as the rig crew was preparing to put a temporary seal on the well and move on to another site. The seal ended up being compromised by the infiltration of explosive natural gas. A backup system, a series of shear rams designed to close off the opening if problems arose, failed, leaving the well to freely release oil into the Gulf of Mexico (Coy \& Reed, 2010). There are differing opinions regarding how much oil was released, but according to government estimates it was at least 60,000 barrels/day, and maybe as high as 100,000 (Weidner, 2010). The coastline states impacted by the oil spill include Louisiana, Texas, Mississippi, Alabama and Florida. The oil killed fish, birds and other wildlife, as well as destroying ecosystems and water based economies, such as fishing and tourism. The full impact and cost of the spill will never be fully appreciated.

BP agreed in June 2010 to set aside $\$ 20$ billion for claims by victims of the spill. This was not a finalized sum but an initial amount. BP also announced suspension of dividend payment and agreed to pay $\$ 100$ million in compensation for thousands of oil-rig workers who lost their jobs (Globe and Mail, 2010). In addition, that June the share value hit a 14-year low of $£ 3.37$, based on the unknown liability of the clean up and claims to be made against BP (Herron, 2010).

Many stakeholders asked why this spill happened and whether BP took adequate safety steps to reduce risk, and if it acted responsibly once the spill occurred. Evaluations were critical of the company in both areas. Federal officials and industry analysts claimed BP lagged behind other companies when it came to safety (Newsweek, 2010). Several factors contributed to the crisis: cost saving, complacency, and possibly arrogance. One law suit filed against BP by a Florida firm, Levin Papantonio Thomas Mitchell Echsner Rafferty and Proctor, alleged BP misled regulators for years regarding the risks involved, and the company's crisis preparedness, while at the same time failing to improve safety practices (Barrett \& Blum, 2010). The law suit argued that BP exaggerated their level of preparation for a deep sea spill. In 2009, the company claimed it had the "capability to respond, to the maximum extent practicable, to a worst-case discharge" (Barrett \& Blum, 2010: 2). The law suit also drew attention to cost cutting the company engaged in. For example, a test to determine if a cement seal had formed fully or would let natural gas out (the source of the explosion) was canceled to save $\$ 128,000$ (Barrett \& Blum, 2010:3). Incredibly, such penny-pinching moves were made as BP racked up record-breaking profits (Edersheim, 2010).

\section{BP: Update}

In 2009 BP replaced its CEO, Tony Hayward, with an American CEO, Bob Dudley. This change at the top was designed to appease public outrage by replacing an apparently uncaring and erring leader with a local, who had a vested interest in getting things right and who had a clean record not being associated with any previous BP accident (Lyall, 2010). Hayward was not fired, but demoted and literally sent to Siberia, to head up BP's Russian operations (Barrow \& Bates, 2010).

In 2010 Congress enacted the Refuse Act, under which BP would be held responsible for the damages in the Gulf (Bowman, 2010). In 2012 BP was found guilty of criminal negligence, with serious criminal charges against three executives (Fowler, 2012). Thus far, BP has paid more than $\$ 14$ billion in clean-up, $\$ 8$ billion in business claims, $\$ 4$ billion in fines, a half a billion dollars in civil penalties, and at a future trial in 2013, is expected to incur massive penalties and further fines (BP, 2012; Kunzelman, 2013). The Financial Times has estimated the continuing costs to BP of the Gulf oil spill may reach 90 billion dollars (Chasan \& Crooks, 2013).

BP has subsidized its costs by selling its 50 per cent stake in the TNK-BP Oil Company operating in Russia, to the Russian conglomerate Rosneft, the world's largest oil company. This gave BP $\$ 15$ billion in cash, and up to 20 per cent shares in Rosneft. At the same time, BP lost a further $\$ 7.2$ billion on failed development in India. BP is cash strapped, and as reported by Fortson in the Sunday Times, "The company is struggling to right itself nearly two and a half years after the Gulf of Mexico oil spill" (2012).

\section{BP: Backstory}

BP's recent history is a litany of environmental and ethical disasters. The history of accidents shows a pattern of behaviour and organizational culture that persisted through the Gulf of Mexico spill. The following are a few highlights; many more incidents can be found.

In 1989 BP was involved in the Exxon Valdez oil spill. BP dominated the Alyeska consortium, a partnership made of seven oil firms. BP held a controlling share of 50.01 percent ownership of Alyeska (CBCNews, 2010). The consortium oversaw the movement of oil through the Trans-Alaska Pipeline System. Alyeska was responsible for the extraction of the oil from the North Slope through the pipeline 800 miles down to the tank loading areas in Valdez. It 
also included the system of moving the tankers down the coast to California. BP, as part of Alyeska, shaped the preconditions that created the hazards in the movement of the oil. After the spill, Alyeska was in charge of the clean up (Democracy Now, 2010). However, because of the poor performance of Alyeska at the time of the spill, the responsibility reverted to Exxon. "Alyeska officials were notified within minutes of the Valdez spill, but it took seven hours for the consortium to get its first helicopter in the air with a Coast Guard investigator. A barge that was supposed to be carrying containment equipment had to be reloaded and did not arrive on the scene until 12 hours after the spill. During the spill, Alyeska only had enough booms to surround a single tanker, not enough to surround the spill. The few skimmers it had to scoop up oil were out of commission once they filled up because no tank barge was available to handle recovered oil." 24 hours after the spill Exxon announced it was taking over the clean up from Alyeska (CBCNews, 2010; Alaska Department of Environmental Conservation, 1993). According to the Alaska Department of Environmental Conversation (1993), Alyeska's response was slow and weak; it did not meet the requirements of the contingency plan.

According to Zygmunt Plater, environmental law professor, Boston College and head of the legal team for the state-appointed Alaska Oil Spill Commission for the 1989 Exxon Valdez spill "the same kind of mega-system problems that we learned lessons from then continued for twenty years with the lessons unlearned" and reappearing later with BP's oil spill in the Gulf. In terms of "contingency planning, it was clear to (the Alaska Oil Spill Commission) that, both before and after, this mega-system was characterized by... complacency, collusion (and) neglect... And twenty years later, we are finding ourselves retracing the same path.” (Democracy Now, 2010).

There are more examples of corporate neglect. In 1991, BP was cited as the most polluting company in the USA, based on EPA standards (Bedder, 2002). In 2005, Multinational Monitor (2013) named BP one of the ten worst corporations in the world, based on its environmental and human rights record. The Multinational Monitor sited the 2005 explosion at BP's Texas refinery as a prime example of the poor corporate behaviour of the corporation. In the explosion fifteen people were killed, over 170 people were injured. BP paid more than $\$ 1.6$ billion to date to settle death and injury claims for the Texas explosion (Goodwyn, 2008). In 2006, the U.S. Occupational Safety and Health Administration levied a record \$21.3 million fine against BP and charged BP with more than 300 willful violations (Belli, 2006). In 2006 BP's Alaskan pipeline ruptured, and subsequent investigations showed this oil spill was a result of improper safety measures and cost-cutting methods. In 2008, BP was accused of bribery and corruption in Grenada and Kazakhstan, (Quinn, Telegraph, 2008). In the 2012 court decision fining BP, the Assistant DA spoke of BP's culture of greed and privilege, and "putting profit before prudence" (Muskal \& White, 2012). Also in 2012, roughly 125 barrels of oil along with $1,600 \mathrm{~kg}$ of gas flowed from a leak in a BP installation on the Ula field within the Norwegian continental shelf (Miller, 2013). Granted that no one in the oil industry is a model corporate citizen, BP's record of harm is still outstanding.

Business ethics lore would suggest that BP, as a broken company whose actions are unsustainable, will soon be an ex-problem. Normally, a company with this kind of record would be on a downward spiral to bankruptcy. BP, however, while feeling the pinch, is far from hitting bottom. Fines and penalties are paid, new deals are made, and for BP, in the same pattern of environmental abuse, it is business as usual. BP made over $\$ 90$ billion in sales in the third quarter of 2012, and over $\$ 5$ billion in profits. BP's PR image is uplifted by the pay out for TV ads for Gulf tourism (Burdeau, 2012), and for the financial support of the 2012 London Olympics (BP, 2013). BP, unlike in the US, has retained its support in the UK. In its home base of the UK, media coverage has convinced the public that most of the damage claims of the Gulf of Mexico disaster were exaggerated, mostly for the US to extort huge sums of money from BP (Jones, 2010).

\section{Crisis Management and Organizational Transformation}

Crisis management calls for a culture transformation. Organizational culture is a system of shared meaning or values within an organization that impacts how employees act. When confronting a decision or problem, the organizational culture influences how employees define, evaluate and address issues. In transforming a corporation, it is very difficult and sometimes unconvincing, to talk about organizational cultural change, or fixing corporate culture, or getting corporations to do the right thing, because of the enormity of the task (Fitzgerald, 1988). The usual claims of how this might be achieved are based on 'magic bullet' theories, such as ousting poor leaders and rogue employees, rewriting company codes, apologizing and paying reparations, all of which have been shown to have limited and inconsistent impact on the organizational culture and the change in culture. Once exposed, however, errant organizations such as BP have little choice but to move from hosting wrongdoing to dealing with it (De Maria, 2010). The question is, how? 
Most studies show that a change in leader personnel has a worsening effect, not a better one (Huberman Arnold and Arnold, 2008). In 2007, when CEO Hayward joined BP the company declared that Hayward's leadership had "fundamentally changed" the culture at the company (Somaiya, 2010), a hollow statement in the aftermath of the oil spill. Ramping up compliance to existing laws, renewed codes, regulations or guidelines, similarly has little effect (Paine, 1995). The integrity strategies described by Paine (and touted by Trevino and Nelson (2007) and Weaver) to transform an organization, have not yielded good results (Paine, 1995 and Weaver, Trevino \& Cochran, 1999). There are very few, if any organizations, where there is a complete and beneficial change of culture from broken to fixed, or from miscreant to trustworthy and ethical. Paine and Trevino and Nelson, between them, cited half a dozen or so organizations they say have culturally turned around, after crises and appropriate integrity strategy crisis management (Paine, 1995 and Trevino \& Nelson, 2007). However, more recent research on those firms, tells a different story. The evidence cited is very tainted: some of their ideal corporations have ceased to exist after crises, some have been fined heavily for breaches of safety, some have been found guilty of bribery and corruption. Sad to say, none of the original listings seems to have a sustainable culture (Huberman Arnold, Arnold \& Arnold, 2010).

We must be cautious of regulations and legislation as a means of transforming corporate behavior. Compliance is weak hand-waving; companies that want to do the right thing and follow rules, do not need to be forced into that position (Andersen, 2009). As well, firms that do not want or believe in the regulations or laws, will not follow the rules, will find ways to appear to be following the rules or will lobby for flexibility in the application of the rules (McKay, 2001). Compliance works at the lowest common denominator; it is a minimalist strategy at best (Paine, 1995). It presents to corporations the least they have to do to stay within the law. We cannot, however, dismiss the value of regulations in the area of sustainability. All one has to do to understand the advantage of regulations is to visit countries where there are minimal environmental regulations, such as China (Stephens, 2009), to recognize the impact of diminished government oversight.

Nevertheless, in the area of sustainability, where leadership and proactive behavior are key, depending on government regulations can be shortsighted. Regulations create a minimum for corporate behavior, but with global trade agreements, many government regulations have been challenged (DePalma, 2002). In the area of sustainability, corporations need to provide leadership rather than lean on the government for direction.

A further reason not to put faith in compliance, centers on the fact that when an organization is failing, or broken, the very system designed to regulate that organization, to make sure it does not break, has also failed. In the case of BP, the government watchdogs and regulators in charge are also to blame, as they seem to have failed to oversee the company and the industry. The U.S. federal Mineral Management Service (MMS) in charge of regulating off shore oil and gas production was overly confident in the safety of deep sea drilling. As a result of this belief, the MMS exempted BP from filing an environmental impact statement for the drill where the spill occurred (Coy and Reed, 2010). BP also took risks. "Lawmakers have said BP ignored warnings from contractors and their own employees and chose faster and cheaper drilling options that increased the danger of the well rupturing" (Doering \& Gardner, 2010). MMS had BP investigate itself, and file its own reports, and left the important technical and safety issues to BP to handle alone (Somaiya, 2010). President Obama also agreed that the regulations were too lax, and set about increasing regulations on deep sea drilling (Yakabuski, 2010). Even the chief executive of BP, Tony Hayward, conceded that more could have been done to make safety improvements (Doering \& Gardner, 2010).

\section{Transformation}

BP may have a tough road ahead, but its host countries, its impacted communities, its employees, and the environment, have a tougher road, if BP fails to change its business ethic and runs roughshod over all of them. Organizations have only a small window of opportunity after a disaster to introduce sustainable change. After the opportunity passes, if the disaster has not been managed with a view to new learning, then the old patterns of behavior return (De Maria, 2010). In order to avoid slipping backwards, De Maria (2010) recommends the organization: 1. is victim focused, 2. accepts responsibility for the crisis, 3. institutionalizes learning (as in the learning organization), and 4. adopts an impression management focus of contrition, cleaning up and improving behavior. BP has done all of the above over the years, but nothing has changed in its culture or operations, and the harm continues. The public has watched, and wait for the change but found an organization where the management is not willing or able to change. Company insiders, past and present, say the disaster was all too foreseeable. They describe BP as a culture of arrogance and risk-taking, spanning decades. Profits came before safety and whistle-blowers were intimidated, pressured out, or fired (Somaiya, 2010).

$\mathrm{BP}$, more than any other company in the industry, has staked its future on aggressive projects. According to the BP exploration and production chief in 2009, "We don't do simple things...We are prepared to work on the frontier and 
manage the risks" (Coy \& Reed, 2010: 53). In addition, BP insulated itself from stakeholders who questioned the advisability of taking these risks. The increased mobility and communication of our society has led to executives and corporate decision makers being able to surround themselves with like-minded people. Actions and beliefs that are contradictory become increasingly difficult to entertain, because it is less and less likely that BP executives are interacting with people who have, or will voice, an alternative opinion on acceptable and unacceptable risk (Haass, 2009).

BP's most unforgivable management error during this crisis was the ineffectiveness of its CEO to deliver messages earning public trust (Weidner, 2010). Also, after the spill it acted in ways that indicate the organizational culture prior to the spill persisted after the spill and stakeholder trust is unwarranted. For example, the use of Corexit, an oil dispersant banned in Europe 10 years ago, only pushes the oil below the surface, where it can cause more damage. This dispersant is highly toxic but hides the oil from view. The Environmental Protection Agency suggested Corexit not be used in the Gulf, but BP ignored their request (Edersheim, 2010). BP was also challenged on its conservative estimates of the amount of oil that has spilled (Edersheim, 2010) and has been charged with fraud regarding these numbers based on company emails. Emails from Kurt Mix, former BP engineer, show that BP knew the flow rate long before they advised US authorities. BP claimed they did not know the spills full extent until after April. However, according to the emails they knew almost immediately. The emails show that just two days after the explosion Mix estimated the flow rate between 62,000 and 146,000 barrels a day. BP executives told the coast guard that their best estimates of leak was 1,000 barrels a day. The chief executive, Bob Dudley, then estimated the flow rate around 5,000 barrels a day, substantially below the estimates given to BP's management (Kennedy, 2012). In addition, BP initially did not accept responsibility for the crisis. Hayward, BP's CEO, insisted the accident was the fault of the drilling company, Transocean, not BP (Coy \& Reid, 2010).

What remains clear is that there are obvious and enormous value deficiencies in the organization, which will not be fixed, and which do not seem to matter to its continued operations all over the world. Shortcomings in the way the organization deals with safety, sustainability, risk, profits and regulations continue. On an individual basis, it is likely many BP employees knew there were problems with the decisions made and the values embraced by the organization. The problem is that the implicit understandings, elephants in the room according to Hammond and Mayfield (2001), such as safety issues, were never made explicit and thus never adequately discussed. Hammond and Mayfield (2004), recommend naming the elephants through three steps. First, identify what is not being discussed. The media and government have assisted in this process by pointing out the corporate weaknesses. The second step requires surfacing underlying assumptions that people hold about the situation. This would be best done through a multi-stakeholder approach. Finally, the organization if it cared about its employees, needs to learn how to have constructive dialogue involving top, middle and bottom level employees. Ideally further research would look at BP by interviewing all employees and relevant stakeholder and looking at these issues more holistically. If the best predictor of future actions is past behaviour, then we can be sure that none of this will happen. BP has enough money and power to remain in business, but the company will ultimately fail all its stakeholders again, evidently with impunity unless stakeholders are given more of a voice.

\section{Conclusion}

The moral of the story of BP is that the traditional business ethics theory that predicts BP-type behaviour will drive a company to destruction, is obviously wrong. Noreena Hertz, in her book The Silent Takeover, compared the most powerful corporations to nation states. Their economies are larger than those of most countries in the world. Their CEOs are like Presidents. They claim sovereignty for their actions, and no one can stop them. BP is sustainable in its current mode of operation based on arrogance and insulation; unfortunately, the rest of the world may not be sustainable due to corporations like BP. Communities and countries need to enforce sustainability rather than wait for corporation to act sustainably.

\section{References}

Alaska Department of Environmental Conservation, (1993). Exxon Valdez oil spill overview. Final Report, State of Alaska Response. Retrieved from January 24, 2013: http://library.thinkquest.org/10867/cleanup/overview.shtml

Anderson, R., (2011). Confessions of a Radical Industrialist: How Interface proved that you can build a successful business without destroying the planet, Random House Business Books; London.

Barrow, B. \& Bates, D. (2010, July 26). Sent to Russia: BP blunderer Hayward to join board of joint venture with 'oiligarchs,' MailOnLine July 26, 2010. Retrieved from January 20 $0^{\text {th }}$ 2013: 
http://www.dailymail.co.uk/news/article-1297816/BP-boss-Tony-Hayward-join-board-joint-venture-Russian-oil igarchs.html

Bedder, S. (2002). bp: Beyond Petroleum? in Battling Big Business: Countering greenwash, infiltration and other forms of corporate bullying, edited by Eveline Lubbers, Green Books, Devon, UK, 2002, pp. 26-32.

Belli, A. (2006, April 29th). BP blast sparks criminal probe. Houston Chronicle. Retrieved from March 30 ${ }^{\text {th }}$, 2013: http://www.alaskaforum.org/2006\%20News\%20Stories\%20Sorted\%20by\%20Month/april_2006_news_stories. $\mathrm{htm}$

Bowman, Q. (2010, June 7). Oil Spill Liability a Complicated Legal Web. PBS NewsHour. Retrieved from March $30^{\text {th }}, 2013$ : http://www.pbs.org/newshour/updates/politics/jan-june10/oillaw_06-04.html

Burdeau, C. (2012, January 8). Locals call BP's feel-good Gulf ads 'propaganda', The Associated Press. Retrieved from March $30^{\text {th }}, 2012:$ http://news.ca.msn.com/top-stories/locals-call-bps-feel-good-gulf-ads-propaganda

BP, (2013). www.bp.com

Carroll, A.B. (1991). The Pyramid of Corporate Social Responsibility. Business Horizons. July-August, 39-48. http://dx.doi.org/10.1016/0007-6813(91)90005-G

CBCNews, (2010, May 25). BP Played Central Role in Exxon Valdez Disaster. Retrieved from January 25 $5^{\text {th }}$ 2010: http:/www.cbsnews.com/2100-201_162-6516877.html

Chasan, G. (London) \& E. Crooks (New York). (2013, Feb 5). Claims may push BP's spill bill to \$90bn Financial Times, Business Report, online. Retrieved from April 24, 2013: http://www.ft.com/intl/cms/s/0/097ca8f4-6f6b-11e2-b906-00144feab49a.html

Coy, P. and S. Reed, (2010). Lessons of the spill. Bloomberg, May 10-16, 48-54.

Crane, A. and D. Matten. (2010). Business Ethics. Oxford U. Press: Oxford, U.K.

Democracy Now, (2010). BP Played Central Role in Botched Containment of 1989 Exxon Valdez Disaster, Wednesday May 26, 2010, Retrieved from January 24 ${ }^{\text {th }}$ 2013: http://www.democracynow.org/2010/5/26/bp_played_central_role_in_botched

De Maria, W. (2010). After the scandal - Recovery options for damaged organizations. Journal of Management \& Organizations, Vol. 16 (1), 66-82. http://dx.doi.org/10.5172/jmo.16.1.66

DePalma, A. (2002. March 1). W.T.O. Pact Would Set Global Accounting Rules. The New York Times. Retrieved from July 21, 2010: http://www.nytimes.com/2002/03/01/business/wto-pact-would-set-global-accounting-rules.html.

Doering, C. and T. Gardner, (2010). BP ‘deeply sorry’ for disaster. Packet \& Times, Worldnews, A11.

Economist Intelligence Unit, (2005). The importance of corporate responsibility: A white paper from the Economist Intelligence Unit. $\quad$ Retrieved from January 20 ${ }^{\text {th }}$, http://graphics.eiu.com/files/ad_pdfs/eiuOracle_CorporateResponsibility_WP.pdf

Edersheim, E. H. (2010). BP Culture's Role in the Gulf Oil Crisis. Retrieved from July 17: $\mathrm{http} / / /$ www.businessweek.com/print/managing/content/jun2010/ca2010068_314614.htm.

Fitzgerald, T.H. (1988). Can change in organizational culture really be managed? Organizational Dynamics, Autumn, 5-15. http://dx.doi.org/10.1016/0090-2616(88)90015-0

Fortson, D. (2012, July 29). BP Profits Tumble By 20\%. The Sunday Times (London), p. 1.

Fowler, T., (2012, November 16). BP hit with $\$ 4.3$ bn penalty, 12 criminal charges over Deepwater disaster. Wall Street Journal. Retrieved from January 2012: http://www.theaustralian.com.au/business/wall-street-journal/bp-hit-with-43bn-penalty-12-criminal-charges-ove r-deepwater-disaster/story-fnay3ubk-1226517818835

Goodwyn, W. (2008). Deal over Texas Refinery Blast Opposed. National Public Radio. http://www.npr.org/templates/story/story.php?storyId=18656603

Globe and Mail. (2010, June 17). \$20-billion just a start - BP's final tab likely to run much deeper. Globe and Mail, A17.

Haass, R. (2009, March 13). Our culture of arrogance and isolation. Huffpost Social News. Retrieved from July 18, 2010: http://www.huffingtonpost.com/john-standerfer/our-culture-of-arrogance_b_174905.html. 
Hammond, S Annis \& A. B. Mayfield, (2010). Naming Elephants. Thin Book Publishing Co.: Oregon.

Herron, J. (2010, July 8). Tony's travels give BP a boost. Wall Street Journal. Retrieved from July 17, 2010: http://blogs.wsj.com/source/2010/07/08/tonys-travels-give-bp-a-boost/.

Hertz, N. (2003). The Silent Takeover: Global Capitalism and the Death of Democracy. Harper Collins: NY, NY.

Huberman Arnold, D., K. Arnold, \& V. Arnold. (2010). Managing Ethical Risks and Crises: Beyond Legal Compliance. Beijing Law Review, Vol. 1, No. 1, Dec. 27, $2010 . \quad$ Pp. 1-6. http://dx.doi.org/10.4236/blr.2010.11001

Huberman Arnold, D. \& K. Arnold (2008). The Myth of Leadership. Doing Business In The Global Economy. Koufopoulos \& Argyropousou eds. Atiner: Athens, 103-117.

Huberman Arnold, D. \& K. Arnold (2003). Global Business Ethics and Codes. Business and Professional Ethics Journal, Vol. 22 (2), 71-88. http://dx.doi.org/10.5840/bpej200322213

Jones, D. (2010, Augusts 6). Disaster that never was: Why claims that BP created history's worst oil spill may be the most cynical spin campaign ever. The Mail Online. Retrieved from April 24, 2013: http://www.dailymail.co.uk/news/article-1301002/BP-oil-spill-Why-claims-Gulf-Mexico-historys-worst-oil-spil 1-cynical-spin-campaign-ever.html?openGraphAuthor=\%2Fhome\%2Fsearch.html\%3Fs\%3D\%26authornamef\% 3DDavid\%2BJones

Karakowsky, L, Archie B. Carroll and Ann K. Buchholtz. (2005). Business and Society. Thomson: Toronto.

Kennedy, C. (2012, December 10). The cover up: E-mails show BP lied to authorities on the Deepwater Horizon spill. OilPrice.com. Retrieved from $30^{\text {th }}$, 2013: http://oilprice.com/Latest-Energy-News/World-News/The-Cover-Up-E-mails-Show-BP-Lied-to-Authorities-onThe-Deepwater-Horizon-Spill.html

Kunzelman, M. (2012, November 15). BP to pay extra US\$4.5-billion, biggest criminal fine in U.S. history, Financial Post. Retrieved from Jan 20 $4^{\text {th }}$, http://business.financialpost.com/2012/11/15/bp-close-to-agreeing-record-oil-spill-fine-sources/

Le Carré, J. (2000). The Constant Gardner. Penguin: Toronto.

Lyall, S. and Werdigier, J., (2010, June 10). U.S. Fury at BP Stirs Backlash Among British. The New York Times. Retrieved from January $20^{\text {th }}$, 2013: http://www.nytimes.com/2010/06/11/business/11bp.html?_r=0

Lyall, S. (2010, July 12). In BP's Record, a History of Boldness and Costly Blunders, The New York Times. Retrieved from January 2013: http://www.nytimes.com/2010/07/13/business/energy-environment/13bprisk.html

McKay, R., D. Huberman Arnold, J. Fratzl, \& R. Thomas (2008). Workplace Bullying In Academia: A Canadian Study. Employee Responsibilities and Rights Journal. Volume 20, Number 2, June 2008, p 77-100. http://dx.doi.org/10.1007/s10672-008-9073-3

McKay, R., (2001). Organizational responses to an environmental bill of rights. Organization Studies, Vol. 22 (4), 625-658. http://dx.doi.org/10.1177/0170840601224004

Mouawad, Jad, (2010, May 8). For BP, a History of Spills and Safety Lapses. New York Times. Retrieved from: http://www.nytimes.com/2010/05/09/business/09bp.html.

Miller, R. (2013, April 30). BP Under Fire for Oil Leak in North Sea. The Times. Tuesday. Business Section, p. 43.

Multinational Monitor. (2013). The 10 worst Corporations of 2005, BP. Retrieved from March 30 2013 : http://www.multinationalmonitor.org/mm2005/112005/mokhiber.html\#BP

Muskal, M. and R. D. White, (2012, November 15). BP Fined. LA Times. Retrieved from March 30, 2013: http://www.ky3.com/news/la-na-nn-holder-bp-oil-spill-settlement-20121115,0,2242109.story?page=2

Paine, L.S. (1995). Managing For Organizational Integrity. Harvard Business Review, March-April, Vol. 72 (2), 106-117.

Putnam, R. D. (2000). Bowling Alone. Simon and Schuster: New York, NY.

Quinn, J. (2008, April 10). BP and its bosses sued over alleged bribery of officials. London Telegraph, pg 1.

Sen, A., (2004). Markets and the Role of Ethics in Capitalism. Moral Issues in Business. Shaw and Barry, eds. 186-193. 
Somaiya, R. (2010, July 17).The Road to Deepwater Horizon. July 13, 2010. New York Times. Retrieved from: http://www.newsweek.com/2010/07/13/the-road-to-deepwater-horizon.print.html

Stephens, B. (2009, August 4). Global Warming and the Poor: Why India and China don't care much about climate change. Wall Street Journal. Retrieved from: July 21, 2010: http://online.wsj.com/article/SB10001424052970204313604574327992553917308.html\#printMode.

Trevino, L. K. \& K. A. Nelson. (2007). Managing Business Ethics. Wiley: Hoboken, New Jersey.

Weaver, G. R., L. Trevino \& P. Cochran (1999). Corporate Ethics Programs As Control Systems. Academy of Management Journal. Vol. 42 (1), 41-57. http://dx.doi.org/10.2307/256873

Weidner, D., (2010, June 17). For BP, the Crisis Has Become One of Leadership. Wall Street Journal. Retrieved from: http://online.wsj.com/article/SB10001424052748704198004575311223956039514.html.

Yasabuski, K. (2010, June 15). Obama invokes Oval Office to rally support. Globe and Mail, Tuesday. News A14. 